to families, in certain cases which do not correspond precisely to the criteria of the Regulations.

The amended Regulations appear below.

Jean-Louis Cayla

Principles and Relations with the Movement

ICRC

\title{
Regulations for the French Fund Maurice de Madre
}

(Adopted by the ICRC Assembly on 9 September 1974

and amended on 9 April 1981 and 13 December 1995)

\section{ARTICLE 1}

The French Fund Maurice de Madre consists of the property bequeathed to the International Committee of the Red Cross under the will made by Comte Maurice de Madre, who died on 25 December 1970.

\section{ARTICLE 2}

1. In accordance with the deceased's last wishes, the income of the Fund and, depending on the circumstances, the capital shall be used to provide assistance for persons of the permanent or temporary staff of the components of the International Red Cross and Red Crescent Movement, such as first-aid workers, delegates or nurses who, in the course of their work or during war operations or natural disasters, have suffered injury and have thereby found themselves in straitened circumstances or in reduced health.

2. If persons specified under paragraph 1 above should lose their lives in the course of their humanitarian mission, a financial subsidy may be paid to their families should the latter find themselves in consequence in such straitened circumstances that aid would be necessary. 
3. The Board may, exceptionally, provide assistance for the training and professional reintegration of:

- staff members seriously reduced in health;

and may come to the aid of:

- close relatives of staff members;

- members of families of deceased staff members, even if their death was due to illness, accident or other causes not directly linked to their work within the Movement.

4. The beneficiaries shall be selected by the Board of the Fund, which shall establish the amount to be paid and the manner of payment.

\section{ARTICLE 3}

1. The Fund shall be administered by a Board composed of five members appointed by the ICRC Assembly, possibly on the Board's recommendation. The Board may propose any person it wishes to take part in its work - in particular a staff member of the ICRC or the Federation, subject to the agreement of the respective organization - or a member of the Comte de Madre's family. The Assembly shall appoint the Chairman of the Board. The Board shall consist of two members, either Committee or staff members, of the ICRC; one staff member of the International Federation of Red Cross and Red Crescent Societies; one member of the Comte de Madre's family, if it wishes to be represented; and a fifth person whose services the Board desires.

2. The members of the Board, except for the representative of the Comte de Madre's family, shall be subject to re-election every four years and may not remain in office for more than three consecutive terms.

3. The ICRC shall be responsible for the secretariat, administration and accounts of the Fund.

\section{ARTICLE 4}

The Fund shall be administered separately from other ICRC property and its accounts shall be separate. They shall be audited each year by an independent firm of auditors. The yearly accounts of the Fund shall be submitted to the ICRC. 
The Board may sell assets forming part of the Fund and may freely reinvest the proceeds of such sales in such a way as to carry out the testator's wishes in the best possible manner.

\section{ARTICLE 5}

Should it become apparent that the testator's wishes can no longer be fulfilled or can be carried out to a small extent only, the Board may recommend the ICRC to appropriate the existing property for other humanitarian and benevolent uses. Such recommendations would be examined in a plenary session of the ICRC, which would reach a decision after further discussions at a subsequent session.

\section{ARTICLE 6}

The present Regulations may be amended under the same conditions as provided for in the ICRC's Rules of Procedure, but the purpose of the Fund, as expressed in the Comte de Madre's general intentions, may not be changed. 